\title{
Policy Implementation And The Promotion Of Service Delivery Within The Public Health Sector In South Africa
}

Melody Brauns, Durban University of Technology, South Africa Malcolm Wallis, Regent Business School, South Africa

\begin{abstract}
The South African healthcare sector stands at the threshold of major restructuring in an attempt to address inadequacies as a result of fragmentation of health services in apartheid South Africa. The level of health services, particularly in rural areas, has decreased and has led to reduced quality and productivity of health services. For individuals residing in rural communities, access to health services can be arduous. Delivery of essential services has to meet the needs of marginalised people who live in remote areas.
\end{abstract}

The health sector is reputed to be good at formulating policies, discussing ideas, making recommendations, and spending resources, but poor on implementing policies. The government insists that the policy framework is transparent and well-defined and that what is needed is effective implementation. Regrettably, the transition of policy into practice is more complex than the perceived judgement of government. Critical concerns regarding issues about how policy can be effectively implemented and who should be responsible for implementation is one of major concern.

Keywords: Service Delivery; Public Policy; Implementation; Public Healthcare; Governance; Accountability

\section{INTRODUCTION}

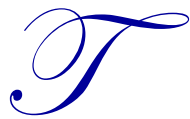

he issue of poor service delivery and ineffective policy implementation, in relation to healthcare, has received considerable critical attention since the turn of the century. The previous Minister of Health, Dr. Manto-Tshabalala-Msimang (Department of Health - DoH, 2000), claimed that since 1994, the post-apartheid government and the DoH had developed and implemented a number of policies and pieces of legislation that impact directly and indirectly on the delivery of health services. South Africa has some of what may appear to be among the world's best policies, yet they sometimes struggle with their implementation.

South Africa has one of the most developed economies in Africa, but the country is plagued with some issues surrounding public healthcare. The state healthcare system is under-resourced and grossly understaffed. This becomes clearer if seen in relation to the health status of the population. For example, the percentage of people living with HIV/AIDS in South Africa is among the highest in the world. According to the Joint United Nations Programme on HIV/AIDS-UNAIDS (2010, p. 180), it is estimated that some 5,600,000 million people have contracted the virus, thereby creating more demand for healthcare as many more people get sick. HIV also undermines the capacity of healthcare workers, many of whom themselves are living with HIV/AIDS.

Furthermore, the country is plagued by four other health problems; namely, TB (directly related to HIV/AIDS), maternal, infant and child mortality, injury and violence, and non-communicable diseases, which represent a burden to performance. In addition, the emergence of extensively drug resistant tuberculosis (XDR-TB) and high rates of HIV/TB co-infection further complicate the response to HIV/AIDS. 
Meyer and Cloete argue that 'bad implementation' has been a major obstacle to progress in developing countries,' a comment which this paper argues is applicable to South Africa (Meyer \& Cloete, 2006, p. 301). The government insists that the policy framework is transparent and well-defined and that what is needed is effective implementation. Regrettably, the translation of policy into practice is more complex than the stated judgements of government. Critical concerns relate to issues about how policy can be effectively implemented and who should be responsible for implementation.

Reasons for policy failure, according to Fox, Bayat, and Ferreira (2006, p. 103), appear to be:

- Those involved in its execution have been uncooperative and/or inefficient or because their best efforts could not overcome obstacles over which they had little or no control.

- $\quad$ The policy itself was bad, in the sense that it was based upon inadequate information, defective reasoning or unrealistic assumptions. This reasoning places in question the perception referred to earlier - that the country has policies of high quality.

Ham and Hawkins (2003, p. 86) claim that the implementation of policies, as a means of improving services in the health sector, will vary depending on the degree of consistency between the values embedded in these policies and those held by actors in the system. This means, for example, health policies that are out of kilter with the assumptions and cultures of practising doctors do not have enough consistency. Their implementation then becomes problematic.

It is also important, particularly in a South African context, to consider the requirements of the constitution. Decisions on service delivery, policies, and the implementation thereof, should be guided by constitutional requirements in the form of the Bill of Rights which aim to:

- $\quad$ Take steps to progressively realise the rights of everyone to have access to healthcare services

- $\quad$ Promote and protect the right of children to basic healthcare services

- $\quad$ Ensure that no one is refused emergency medical treatment (Sections 27(1) (a), (2) and (3) and Section 28(1) (c) of the Constitution of the Republic of South Africa, 1996).

According to Cloete (1998, p. 159), policy making is a prerequisite for the provision of goods or services, at least in theory if not in practice. Officials within the public health sector concerned with the formulation and the implementation of policy must always be aware of techniques that may be used to improve the performance of the actors involved. Policy-making involves identifying needs, preparing legislation, and the analysis of existing policies, whilst policy implementation involves setting missions/objectives/goals, planning, programming, marketing, identifying, and reporting shortcomings.

\section{HISTORICAL BACKGROUND}

Prior to 1994, public health services were fragmented to perpetuate discrimination. The system was founded on an apartheid ideology that was characterised by racial and geographical differences. The people who needed health services the most were denied such services. Apartheid was a system based essentially on such deep discrimination that it robbed Black people of all human dignity. This racism was demonstrated in every aspect of health, such as rigid segregation of health facilities; disproportionate spending on the health of Whites as compared to Blacks - resulting in world-class medical care for Whites while Blacks were usually referred to congested and dirty facilities; public health policies that disregarded diseases primarily affecting Black people; and the denial of basic sanitation, supply of clean water, and other components of public health to rural areas and townships.

One of the important political changes post-1994 was the translation of the 1993 Interim Constitution into a final constitution that guarantees social and economic rights such as adequate housing, education, and health facilities for all South Africans. The elected ruling party set the stage to address the past and make the necessary legislative changes to start providing not only democracy but also access to healthcare for all (Ngwena, 2001/2, pp. 26-44). 
Since 1995, the South African public service has been engaged in the process of transforming itself in an efficient, effective, democratic, and development-oriented instrument of service delivery.

Based on this historical background, reform in all the public services was necessary to redress the past imbalances that existed.

\section{Defining Public Policy}

The most concise definition of a public policy probably remains as set out by Dye (1992, p. 4) who defined public policy simply as what governments choose to do or not to do. Lineberry $(1977$, p. 2$)$ concurs, maintaining that public policy "is what governments do and fail to do - to and for their citizens." Lasswell and Kaplan (1970, p. 177) define public policy as "a projected programme of goals, values and practices," whilst Anderson (2006, p. 6) defines public policy as a "purposive course of action followed by an actor or set of actors in dealing with a problem or matter of concern." Frederich (1963, p. 79) suggests that public policy is "a proposed course of action of a person, group or government within a given environment providing obstacles and opportunities which the policy was proposed to utilize and overcome in an effort to reach a goal or realize an objective or purpose."

These definitions do not negate the possibility that there will be differences between what government decides to do and what they actually do. Public policies centre on what Easton (1953, p. 129) described as "the authoritative allocation of values for the whole society." The study of public policy is hence concerned with, according to Parsons (1995, p. xv), "How issues and problems come to be defined and constructed and how they are placed on the political and policy agenda."

\section{What is Policy Implementation?}

Implementation cannot succeed or fail without a goal against which to judge it (Pressman \& Wildavsky, 1984, p. xxii).

Scholars like Van Meter and Van Horn (1974, pp. 447/8) defined policy implementation as actions taken by the public, individuals and groups that affect the achievements of objectives. Implementation, according to Anderson (2006, p. 193), means "whatever is done to carry a law into effect, to apply it to the target population." A widely used definition is provided by Pressman and Wildavsky (1984, p. xxi) who maintain that "implementation means to carry out, accomplish, fulfil, produce, complete." Yet, what is it that is being implemented? Policies naturally. They maintain that there must "be something out there" to implement - otherwise there would be nothing to move toward in the process of implementation.

Policy implementation uncovers the strengths and weaknesses of the decision-making process. According to Hanekom (1987, p. 3), the making and implementation of policies are inseparably joined and equally important. However, he also maintains that the real test lies in their implementation when the intentions of the policy-maker are put to the test. Policy implementation is the duty of various bodies such as government departments, municipalities, courts of law, interest groups, and communities. Once policies have been formulated, the process of implementation is not always guaranteed to succeed.

Ingram and Mann (1980, p. 12) explain that implementation failure or success is "reflective of an individual's goals, perceptions of need, and perhaps even psychological disposition towards life." One definition of policy success, according to McConnell $(2010$, p. 351), is that "a policy is successful if it achieves the goals that proponents set out to achieve, attracts no criticism of any significance, and support is virtually universal." The first advantage of this definition, according to McConnell, is that it recognizes it is possible for government to attain the goals it seeks to achieve and, secondly, it recognizes that not everyone will perceive government's achievements as successful. Policy failure, according to McConnell (2010, pp. 356-357), is the mirror image of success: "a policy fails if it does not achieve the goals that proponents set out to achieve, and opposition is great and/or support is virtually non-existent." McConnell (2010, p. 357) maintains that policies not only fail to accomplish what they were intended to do but can also threaten the position of politicians and parties that sponsor failed programs. 
Brinkerhoff and Crosby (2002, p. 25) developed a framework that categorised policy implementation into six tasks; namely:

$\begin{array}{ll}\text { - } & \text { Creating legitimacy } \\ \text { - } & \text { Building constituencies } \\ \text { - } & \text { Accumulating resources } \\ \text { - } & \text { Modifying organisational structures } \\ \text { - } & \text { Mobilising resources }\end{array}$

Each of these tasks calls for precise managerial attention, and failure to do so could possibly contribute to the breakdown between policy intent and implementation outcomes (Brinkerhoff \& Crosby, 2002, p. 25).

\section{Understanding Implementation Pitfalls}

Khosa (2003, p. 49) states that "those who make the decisions may lack the capacity to implement," suggesting that translating decisions into action has been unbalanced over time. Khosa goes on to mention that reasons for failure to implement policies may vary from capacity constraints to logistical issues. Another key finding is that many policies are overambitious (thus lacking quality) and therefore unrealistic. An important point to consider is insufficient and ineffective staff at all spheres of government which has contributed toward unsuccessful policy implementation. Such findings would have an unfavourable effect on successful service delivery.

The introduction of new legislation regarding transformation and service delivery brought about a change in how the South African public service was expected to function. The publication of the White Paper on the transformation of public service (1995) served as a point of departure for the transformation of the South African public service. One of the important political changes post-1994 was the translation of the 1993 Interim Constitution into a final one that guarantees, amongst others, access to health services for all citizens. The long delayed National Health Act (NHA) (61 of 2003) can be regarded as the most important law setting out the legislative framework for healthcare delivery in South Africa, replacing the previous Health Act which focused on the apartheid era. The White Paper on the transformation of the health system in South Africa (1997) established a detailed framework for healthcare delivery and identified the manner in which government intended to transform South Africa's healthcare system.

\section{Translating Health Policies into Practice}

Fonn, Xaba, Tint, Conco, and Varkey (1998, p. 22) suggest that significant interventions were made earlier within the health sector to improve access to healthcare. For example, the country has moved toward a district-based primary healthcare system and has made considerable progress in creating policies, especially in reproductive health. SAnews (26 April, 2013) reported South African Deputy President, Kgalema Mothlanthe, as stating that "progress has been made with the implementation of the world's biggest antiretroviral (ARV) programme, with 1.9 million South Africans now receiving ARV medication."

Cooper, Morroni, Omer, Moodley, Harries, Cullingworth, and Hoffman (2004, p. 78) claim that over the past 10 years, the South African government's policy on HIV/AIDS has been ambiguous, often imparting confusing and contradictory messages to healthcare providers and the public. The HIV/AIDS/STI strategic plan for South Africa (2000-2005), according to Cooper et al., focused almost exclusively on prevention through condom promotion, voluntary testing and counselling, and treatment of STIs and opportunistic infections. There was no AIDS treatment policy or plans to implement one. In 2003, the government approved a plan to implement public sector antiretroviral treatment (ARV) for people with AIDS, proposing to have at least one treatment site in every local municipality within five years.

According to Lynam (2006, p. 15), there are, however, challenges in translating health policies into practice. Brinkerhoff and Crosby (2002, p. 6) mention that successful policy outcomes are not only dependent on good policies but upon managing their implementation. 


\section{The Decay of Public Hospitals}

The following section provides an analysis of the poor functioning of the health sector and the role that policy implementation plays/should play to remedy ineffective service delivery.

Since the dawn of democracy, South Africa has undeniably made in-roads into ensuring that "people live better." Yet, the past nineteen years have seen many citizens homeless, jobless, poverty stricken, and destitute. The public health sector, in particular, is increasingly regarded as dysfunctional and inefficient. South Africa faces a shortage of healthcare practitioners which can be attributed to long and inconvenient working hours, uncompetitive salaries, poor working conditions, and a lack of safety. These unfavourable working conditions have resulted in healthcare practitioners pursuing careers outside of South Africa, placing a strain on an already overburdened system. As a result, this has brought about diminished access to healthcare for vulnerable citizens and an increase in overcrowding and waiting times. Citizens' response to poor/non-service delivery has often resulted in militant protests, culminating in violent clashes between the law and protesters.

In an endeavour to understand the inner working of the health sector, this section is aimed at understanding staffing issues as a major contributor to the dysfunctionality of public hospitals. It would be a disservice, not only to the citizens of this country but also the government, to make it appear that hospitals are performing better than they really are. Other issues that contribute to hospital dysfunctionality and management failure range from soiled linen, filthy wards, outdated/broken equipment, unfilled posts, staff burnout, non-availability of drugs, improper procurement practices, budget irregularities, lack of discipline, ageing infrastructure, and a high burden of disease the issues are endless.

Using the public health sector as a point of departure, this article focuses on staffing as a key implementation issue at Montebello Hospital, which is the case study of this article. This is a District Hospital in the iLembe Health District, which serves a population of $\pm 180,000$ people. It is located in a rural area serviced by the Ndwedwe Local Municipality in the iLembe District of KwaZulu-Natal.

Staffing at a District Hospital - Doctors and Nurses

In an interview on 08 October, 2012, the acting Human Resource Manager described the staffing situation:

The hospital employs eight doctors on a full-time basis and eight doctors on a part-time basis. The current vacancy rate for doctors stands at 12. Funds have been budgeted for the vacant posts and the posts have been advertised. However, it has proved difficult in terms of attracting, recruiting and retaining doctors in rural areas because they do not want to live in such areas. Scarcity of doctors in rural areas can be attributed to various factors such as non-availability of schooling for their children, long distances to travel for recreation, burnout due to longer hours and a shortage of staff, lack of equipment, and lack of work opportunities for spouses of health workers.

Doctors leave rural areas in droves for better conditions elsewhere. Every time a rural community, such as Montebello, loses one of its doctors, the impact is severe because these communities can't easily fill the doctor vacancy. The loss of one doctor in that community means that people may have to travel to Appelsbosch Hospital, which is located in the uMgungundlovu health district $- \pm 18 \mathrm{~km}$ 's - to receive medical attention.

People living in rural areas generally have poorer health outcomes, higher rates of chronic disease, and die unnecessarily because of where they live. With rural KwaZulu-Natal already experiencing chronic doctor shortages and higher rates of illness and death, it is essential that doctors fulfil their community service obligations both in terms of giving back to the community and also acquiring the necessary skills and work experience (Ngcobo, 2012, p. 1). 
Table 1 indicates that the iLembe district has a vacancy rate of $48 \%$ for doctors.

Table 1: Vacancy Rate per District

\begin{tabular}{|l|c|c|c|c|}
\hline Vacancy Rate Per District & Doctors & Pharmacists & Professional Nurses & Specialists \\
\hline Ugu & $39 \%$ & $49 \%$ & $32 \%$ & $86 \%$ \\
\hline UMgungundlovu & $33 \%$ & $25 \%$ & $12 \%$ & $53 \%$ \\
\hline uThukela & $56 \%$ & $62 \%$ & $25 \%$ & $79 \%$ \\
\hline uMzinyathi & $58 \%$ & $47 \%$ & $15 \%$ & $100 \%$ \\
\hline Amajuba & $35 \%$ & $28 \%$ & $11 \%$ & $61 \%$ \\
\hline Zululand & $64 \%$ & $43 \%$ & $23 \%$ & $100 \%$ \\
\hline UMkhanyakude & $60 \%$ & $48 \%$ & $24 \%$ & $100 \%$ \\
\hline UThungulu & $45 \%$ & $48 \%$ & $17 \%$ & $65 \%$ \\
\hline iLembe & $48 \%$ & $23 \%$ & $37 \%$ & $65 \%$ \\
\hline Sisonke & $69 \%$ & $64 \%$ & $31 \%$ & $86 \%$ \\
\hline eThekwini & $39 \%$ & $19 \%$ & $23 \%$ & $41 \%$ \\
\hline
\end{tabular}

Source: Ngcobo (2012, p. 1)

Of the 11 districts that were surveyed, iLembe represents the sixth highest district in terms of vacant posts for doctors. The vacancy rate for pharmacists in the iLembe district is $23 \%$, compared to $62 \%$ in the uThukela district. ILembe district has the highest vacancy rate of professional nurses (37\%), whilst specialists constitute $65 \%$ of the vacancy rate in iLembe.

The hospital is experiencing a shortage of nurses in specialised areas such as theatre, nursing science, and primary healthcare. Long and inconvenient working hours, uncompetitive salaries, poor working conditions, and a lack of safety are some of the reasons for nurse shortages. The shortage of nurses at the hospital and across South Africa can also be attributed to decreasing numbers of nurses being trained in the country because there are not enough training colleges and lack of faith in the profession. These unfavourable working conditions have resulted in nurses and doctors pursuing careers outside of South Africa.

\section{DATA ANALYSIS AND FINDINGS}

This section analyses data gathered from questionnaires conducted with participants; namely, patients and healthcare practitioners at Montebello Hospital.

On average, the out-patient department (OPD) at Montebello Hospital services 3,700 patients per month. The sample consisted of 100 male and 100 female patients. At the time of conducting the questionnaire, the number of nurses employed at Montebello Hospital was 176 and the sample consisted of 50 nurses. The number of doctors employed at the hospital is 16 and the questionnaire was administered to 13 doctors (eight full-time and five parttime).

Figure 1 indicates that the highest proportion of patients that strongly agree with this statement are those who frequent the hospital at least once a month (slightly more than $40.0 \%$ ), followed by those who visit the hospital once in two weeks (slightly less than 10.0\%). However, the overall proportion of those who disagree is insignificant.

The findings indicate that most of the population surrounding the hospital does not have a choice of hospitals. They depend on the knowledge and skill of the healthcare practitioners at Montebello to cater to their healthcare needs. More than just knowledge and skill is required; they should be courteous and easily gain the confidence and loyalty of the patient, while portraying a positive image of the institution. Unreliable staff, bad attitudes, and scarcity of staff are challenges that may prevent South African public hospitals from complying with legislation in terms of successfully rolling out NHI. 


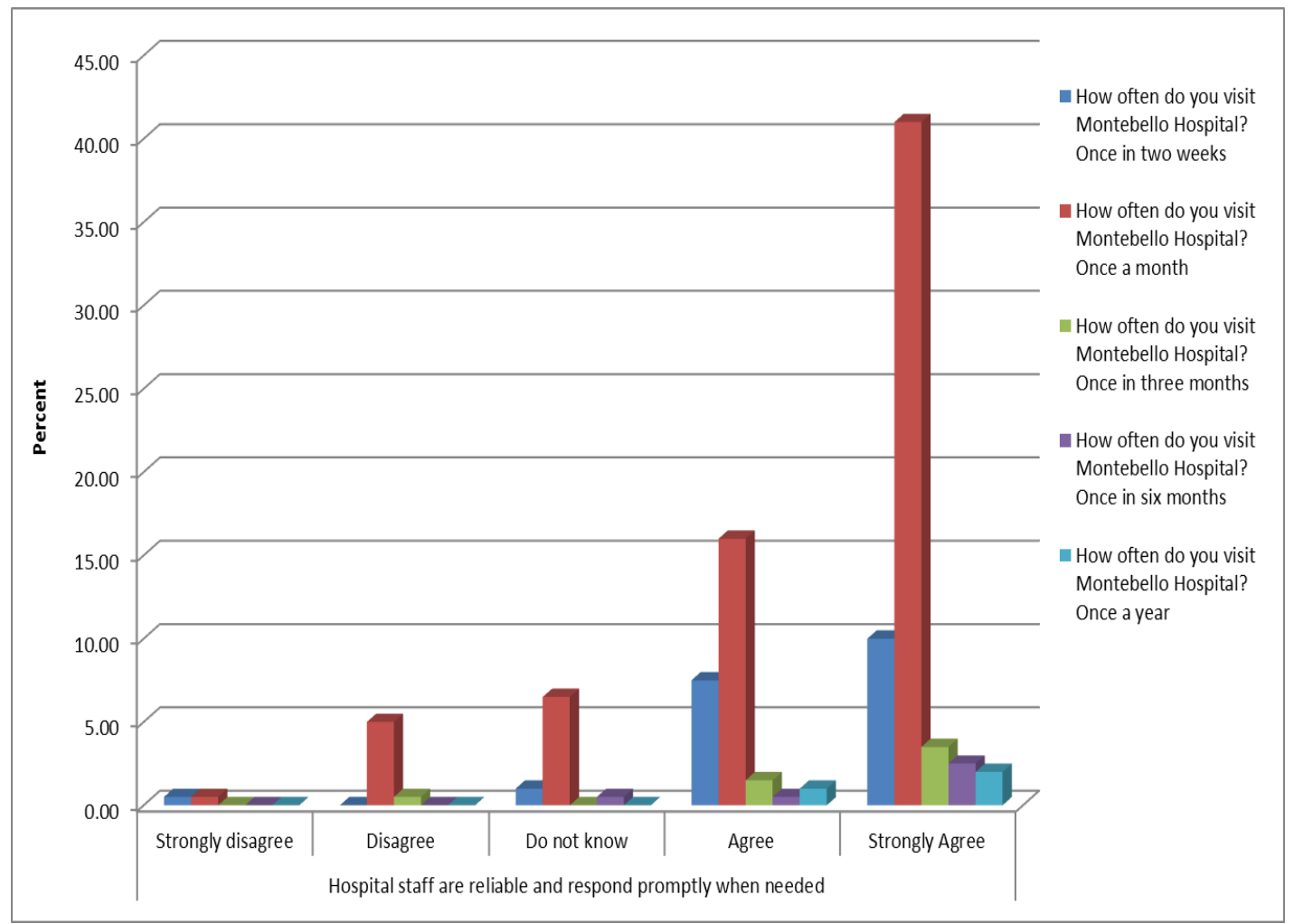

Figure 1: Reliability of Staff - Patient Response

There are high levels of agreement between healthcare professionals who believe that their performance should be monitored on a regular basis. Figure 2 indicates that $10.0 \%$ of doctors disagree with this statement, while $8.0 \%$ of nurses disagree. Exactly half $(50.0 \%)$ of the doctors maintain that issues of remuneration and ageing infrastructure contribute to the demotivation of medical staff. Less than half (40.0\%) of the nurses support the doctors on this issue.

There is a difference of $8.0 \%$ between doctors and nurses who maintain that political leaders have not ensured the sound management of finances and human resources, while there is a difference of $2.0 \%$ who believe that political leaders have ensured the sound management of finances and human resources. Exactly half (50.0\%) of doctors are of the view that medical staff are not under-resourced, while $36.0 \%$ of nurses agree with this statement. Less than half (48.0\%) of nurses believe that medical staff are under-resourced and $30.0 \%$ of doctors support this statement.

The findings indicate that the issue of doctors being overworked is not new to South Africa and, indeed, to Montebello Hospital. Posts have been advertised and still remain unfilled. Doctors constantly work under pressure. There is a lack of adequate staff and equipment, resulting in patient care being diminished. Skilled and experienced doctors are reluctant to occupy posts in rural areas, such as Montebello, due to these issues and yet government does not provide an attractive incentive for medical practitioners to work in such areas. 


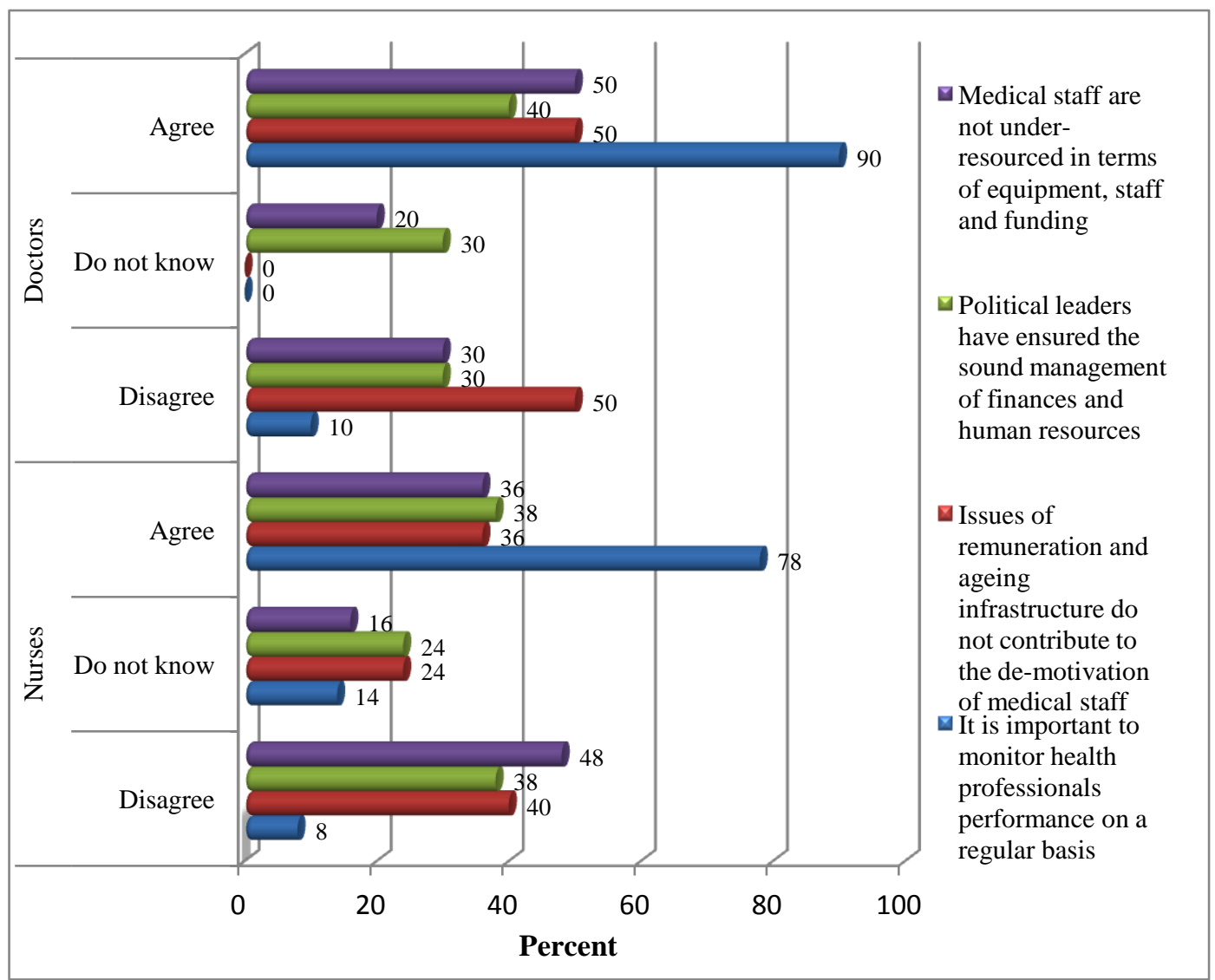

Figure 2: Availability of Resources, The Management of Finances, and Issues of Remuneration - Doctors and Nurses Response

Figure 3 indicates that there is a difference of $16.0 \%$ between doctors and nurses who believe that the Batho Pele principles are being practised at Montebello Hospital. Only $10.0 \%$ of doctors disagree with this statement, while $4.0 \%$ of nurses believe that the Batho Pele principles are not being practised. There is a $50.0 \%$ disparity between doctors and nurses who believe that there is no risk of collapse if underpaid and overworked doctors leave the public healthcare sector. More than half $(60.0 \%)$ of the nurses disagreed with the second statement, maintaining that should underpaid and overworked doctors leave the public healthcare sector, there is a risk of collapse. Only $10.0 \%$ of doctors disagreed with the second statement. Doctors tend to agree that professionals migrate to areas where they believe their work will be more thoroughly rewarded. Nurses were also in agreement with this statement, although slightly less so than doctors.

The findings indicate that the environment in which healthcare practitioners operate plays an important role in retaining their services. Proper housing, infrastructure, equipment, and job rotation are elements that the government must take cognisance of in order to attract and retain doctors in rural areas. Another protest for doctors in such areas is the issue of major discrimination in remuneration. Doctors who work in urban public hospitals receive the same incentive as those who are employed in rural areas. In spite of limited resources, healthcare practitioners agree that the Batho Pele principles are being practised at the hospital. 


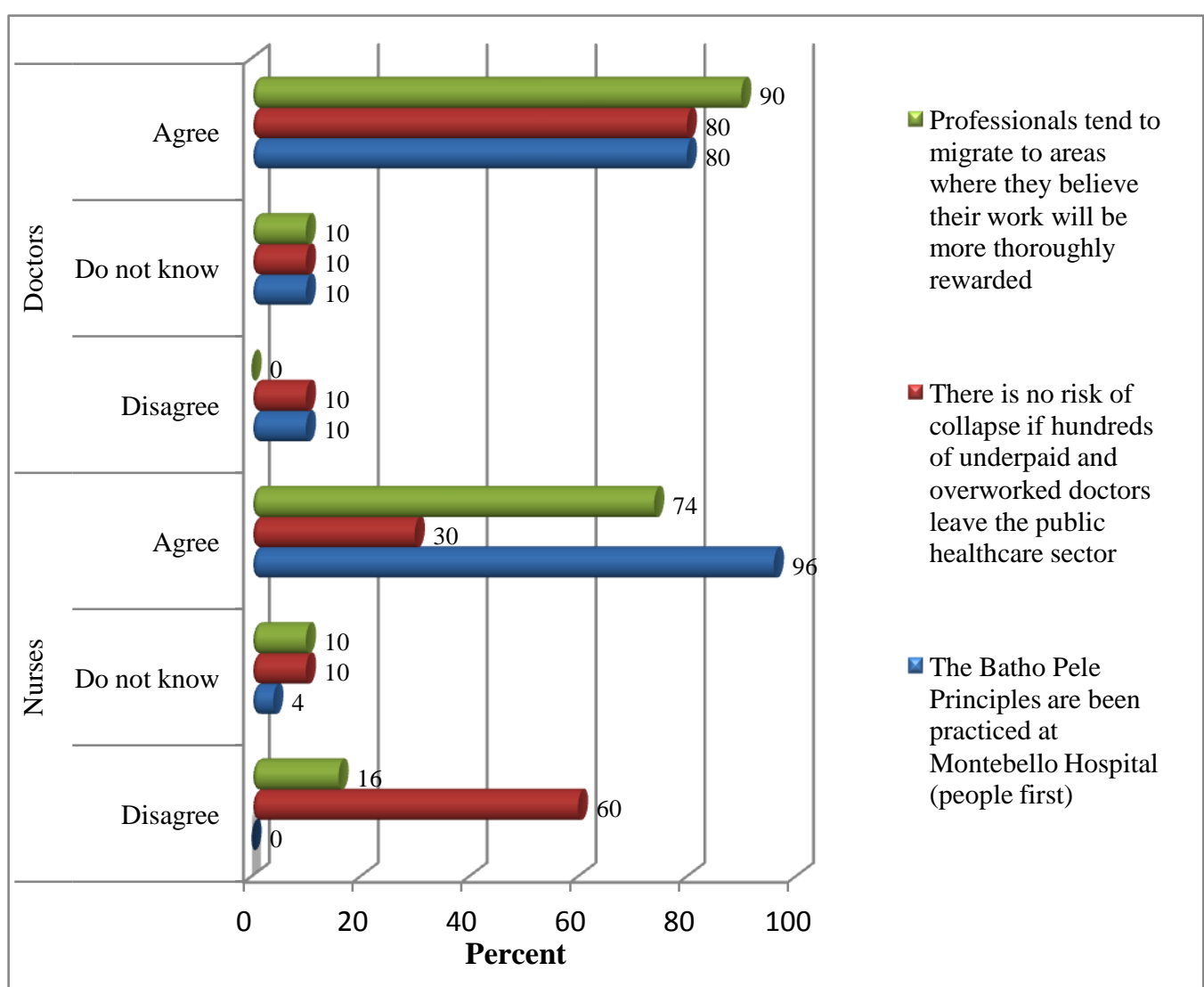

Figure 3: Work Reward, Overworked Doctors Leaving the Public Healthcare Sector, Implementation of the Batho Pele Principles - Doctors and Nurses Response

\section{RECOMMENDATIONS CONCERNING STAFFING AT THE HOSPITAL}

Healthcare practitioners play an important role in patient satisfaction. Despite their courageous efforts, those who depend on public health services are frequently unable to access an acceptable level of healthcare. The conditions that patients are subjected to can be regarded as abuse of human rights. When patients lie unwashed or share a bed with another patient, they are left in soiled bed sheets and urine is seldom collected from wards, staff is in short supply, equipment is outdated, and hospital buildings are run down, it becomes obvious that the rights of patients are not being respected and that urgent action is required. Unfortunately, the shortage of doctors and nurses at this hospital poses constraints on health service delivery. In order to restore a climate of compassion and care, it is therefore suggested that the following recommendations be considered regarding staffing at the hospital:

1. Implement an incentive scheme that would encourage doctors to work in rural areas. This scheme should take into account the availability of schooling for their children, suitable accommodations, and scarce skills allowances.

2. Sound leadership and management skills are important in ensuring patient satisfaction. The hospital manager must pay specific attention to the environment when planning and organising resources for quality healthcare. Thus, it is significant to bear in mind that an analysis of planning and managing political, social, economic, technological, and cultural aspects is fundamental to the functioning of the hospital.

3. With the intended implementation of NHI, provision must be made for managers to improve performance and build a firm foundation of public trust. The health department needs to instil greater performance orientation among public servants. This signifies that performance management must become vital to the work of hospital managers. They need to be prepared for the challenges that will confront them as they seek to ensure accountability and avoid bias. Beyond this, public managers' should work to reduce waste, pursue public interest, and advance a strong sense of public ethics. 


\section{CONCLUSION}

South Africa stands at the threshold of revolutionising the entire healthcare sector. This study indicates that the way towards improved service delivery is through participation, community involvement, greater commitment from government, better governance, accountability, transparency, and improved political purpose within the DoH.

Doctors in private practice will be instrumental in strengthening the success of the government's proposed NHI. They should be compensated with an adequate wage if they are to set aside three hours of their working day to look after patients in the public sector - as proposed in the new draft policy. According to Health Minister, Aaron Motsoaledi, the DoH will guarantee the payment of private general practitioners who work in public clinics in the NHI pilot districts. Encouraging foreign doctors to work in rural areas could reduce staff shortages. However, the Health Professions Council of South Africa takes an excessively long time to register these doctors and staff appointments can take up to five months to be approved. Thus, doctors resort to finding employment in the private sector or abroad. In order to deal with the shortage of doctors in South Africa, Doctor Aaron Motsoaledi announced that the number of matriculants sent to Cuba for medical training would increase dramatically - 1,000 matriculants will leave in September 2012. So far, 304 doctors have been trained in Cuba, where 406 are currently studying and 98 will graduate this year. Only 1,200 doctor's graduate from South Africa's eight medical schools each year (Wild, Kahn, Gernetzky, Child, \& Beukes, 2012).

Government has the prime responsibility of ensuring access to healthcare for all, especially for the most vulnerable groups. It is important for government to ensure that services are brought closer to the people and that communities be made aware of services being rendered pertaining to where, how, and when services will be delivered. The Batho Pele White Paper requires departments to set standards which should then be published and communicated to citizens. Government must ensure that hospitals and clinics have fully equipped offices with staff that display the necessary knowledge and skills.

\section{AUTHOR INFORMATION}

Melody Brauns graduated Honours from Durban University of Technology in South Africa and thereafter completed a full Masters dissertation. She is currently pursuing her Ph.D. studies at the University of KwaZuluNatal where her area of specialisation is in the public sector. To date, she has attended two conferences where two articles have been published and another pending. Melody lectures Public Management and also coordinates workintegrated learning for Public Management students. E-mail: melodyb@dut.ac.za (Corresponding author)

Malcolm Wallis has worked for Regent Business School in Durban for almost two years, having previously held senior academic positions at the Durban University of Technology and the former University of Durban-Westville. He has also worked at universities in Kenya, Lesotho, the UK, and Zambia. He is an active member of the African Association of Public Administration and Management from which he received a Gold Award for services to Public Administration in Africa in 2011. His main research interest is in the decentralization of government. In recent years, he has researched and published on local economic development, health policy, and the global economic crisis. He is currently editing a book on service delivery and decentralization in Africa.

\section{REFERENCES}

1. Anderson, J. E. (2006). Public policymaking: An introduction ( $6^{\text {th }}$ ed.). California: Wadsworth Cengage Learning.

2. Brinkerhoff, D. W., \& Crosby, B. L. (2002). Managing policy reform: Concepts and tools for decisionmakers in developing and transitioning countries. Bloomfield, CT: Kumarian Press. Retrieved 29 June 2013 from

http://books.google.co.za/books?id=3L6KC27OyB4C\&pg=PA380\&dq=lack+of+human+resources+in+im plementing+public+policy\&hl=en\&sa=X\&ei=C4WTUfTkM4TssgaO44HYDA\&ved=0CFAQ6AEwBg\#v= onepage \&q=lack $\% 20 \mathrm{of} \% 20 \mathrm{human} \% 20$ resources $\% 20$ in $\% 20$ implementing $\% 20$ public $\% 20$ policy $\& \mathrm{f}=$ false

3. Cloete, J. J. N. (1998). South African public administration and management. Pretoria: Van Schaik Publishers. 
4. Cooper, D., Morroni, C., Omer, P., Moodley, J., Harries, J., Cullingworth, L., \& Hoffman, M. (2004). Ten years of democracy in South Africa: Documenting transformation in reproductive health policy and status. Reproductive Health Matters, 12(24), 70-85.

5. $\quad$ Dye, T. R. (1992). Understanding public policy ( $7^{\text {th }}$ ed.). New Jersey: Prentice Hall.

6. Easton, D. (1953). The political system. New York: Knopf.

7. Fonn, S., Xaba, M., Tint, K. S., Conco, D., \& Varkey, S. (1998). Reproductive health services in South Africa: From rhetoric to implementation. Reproductive Health Matters, 6(11), 22-32.

8. Fox, W. Bayat, M. S., \& Ferreira, I. W. (2006). A guide to managing public policy. Cape Town, Juta \& Co. Ltd.

9. Frederich, C. J. (1963). Man and his government. New York: McGraw Hill.

10. Ham, C., \& Hawkins, L. (2003). Innovations in health service delivery. The corporatisation of public hospitals. Washington: The World Bank. Retrieved 29 June 2013 from

http://books.google.co.za/books?id=iFIVuwFa7GEC\&pg=PA86\&dq=the+relationship+between+policy+im plementation+and+service+delivery $\&$ hl=en $\& s a=X \&$ ei $=1 m O T U a-$

0JsOStAbvmIHgDg\&ved=0CEoQ6AEwBA\#v=onepage\&q=the\%20relationship\%20between $\% 20$ policy $\% 2$ 0implementation\%20and\%20service\%20delivery\&f=false

11. Hanekom, S. X. (1987). Public policy: A framework and instrument for action. Johannesburg: Macmillan.

12. Ingram, H. M., \& Mann, D. E. (1980). Why policies succeed or fail? California: Sage Publications.

13. Khosa, M. M. (2003). Towards effective delivery. Synthesis report on the project entitled 'closing the gap between policy and implementation in South Africa.' (Research Report No. 98.) Johannesburg: Centre for Policy Studies.

14. Lasswell, H., \& Kaplan, A. (1970). Politics. New York: Krager Publishes.

15. Lineberry, R. L. (1977). American public policy: What government does and what difference it makes. New York: Harper and Row.

16. Lynam, S. (2006). Community development and public policy. Combat poverty. Retrieved 29 June 2013 from http://books.google.co.za/books?id=1q_cuAdnW9EC\&pg=PA15\&dq=public+policy+implementation+chal lenges\&hl=en\&sa=X\&ei=bHuTUbqGDI-

Mswb68IHgDA\&ved=0CGMQ6AEwCQ\#v=onepage\&q=public\%20policy $\% 20 \mathrm{implementation} \% 20 \mathrm{challen}$ ges $\& \mathrm{f}=$ false

17. McConnell, A. (2010). Policy success, policy failure and grey areas in-between. Sydney: Cambridge University Press. Government and International Relations, 30(3), 346-362.

18. Ndamane, M. J. (2012). Interviewed by M. Brauns. Durban University of Technology, Pietermaritzburg, $08^{\text {th }}$ October, 2012.

19. Meyer, I. H., \& Cloete, F. (2006). Policy dynamics: Change, failure and success. In F. Cloete, H. Wissink, \& C. De Coning (eds), Improving public policy: From theory to practise. Pretoria: Van Schaik Publishers.

20. Ngcobo, G. (2012). Vacancies cripple health. The Natal Witness, 31 August 2012.

21. Ngwena, C. (2001/2). The recognition of access to healthcare as a human right in South Africa: Is it enough. Health and Human Rights, 5(1), 26-44.

22. Parsons, W. (1995). Public policy. Cheltenham: Edward Elgar.

23. Pressman, J. L., \& Wildavsky, A. L. (1984). Implementation: The Oakland Project. Los Angeles: University of California Press.

24. Republic of South Africa. (1997). Department of Health: White Paper for the Transformation of the health system in South Africa. Pretoria: Government Printers.

25. Republic of South Africa. (1996). The Constitution of the Republic of South Africa (Act No. 108 of 1996). Pretoria: Government Printers.

26. Republic of South Africa. (2000). HIV/AIDS/STD Strategic Plan for South Africa. Pretoria: Government Printers.

27. Republic of South Africa. (2003). National Health Act. Retrieved 29 June 2013 from http://www.google.co.za/url?sa=t\&rct=j\&q=the $\% 20$ national $\% 20$ health $\% 20$ act $\&$ source $=$ web $\&$ cd $=1 \& v e d=0$ CGUQFjAA\&url=http\%3A\%2F\%2Fwww.info.gov.za\%2Fview\%2FDownloadFileAction\%3Fid\%3D6803 9\&ei=hwmxT7WiPIT64QS2lbHPCQ\&usg=AFQjCNEHWPMMEB5AeY2NEoFoi5BajAv0GA

28. SAnews. (2013). SA 'making progress against HIV'. Retrieved 29 June 2013 from http://www.southafrica.info/about/health/aids-260413.htm 
29. UNAIDS (2010). Report on the Global AIDS Epidemic. Retrieved 29 June 2013 from

http://www.unaids.org/documents/20101123_GlobalReport_Annexes1_em.pdf

30. Van Meter, D. S., \& Van Horn, C. E. (1974). The policy implementation process: A conceptual framework. Administration and Society, 6(4), 447-448.

31. Wild, S., Kahn, T., Gernetzky, K., Child, K., \& Beukes, W. (2012). Doctors will get NHI pay. Board of healthcare funders of Southern Africa, 06 July, 2012. Retrieved 28 June 2013 from

http://www.bhfglobal.com/doctors-will-get-nhi-pay-06072012 